\title{
The Classical Foundations of Population Thought: From Plato to Quesnay
}

\author{
by Yves Charbit \\ Dordrecht (Netherlands): Springer 2010 \\ ISBN 978-9048192977 \\ Hardcover, \$139, 186 pp. \\ Reviewed by Fernando Rajulton \\ Department of Sociology, University of Western Ontario (London, Canada) \\ fernando@uwo.ca
}

The main aim of this book is to describe systematically the evolution of ideas on population in past societies, and the "wider historical, demographic, social, economic, cultural and political context in which ideas on population crystallized" (page 2). The book therefore deals with a historical period prior to the birth of demography as science. There are six chapters, covering about 160 pages, four of which examine the ideas on population as expressed by Plato in his views of the city (Chapter 2), by Jean Bodin in his views on power and sovereignty (Chapter 3), by Jean-Baptiste Colbert as a proponent and representative of mercantilism (Chapter 4), and by François Quesnay and the physiocrats in their innovative economic theory of capital, growth, and freedom from trade and production. The other two chapters make up a sort of introductory and concluding remarks of the author on the evolution of population thought. There is no Foreword to the book, perhaps because some of these chapters were already published in journals like Population.

As a "conceptual and methodological preamble" to this historical study on population, Chapter 1 clarifies three key terms used throughout the book, namely, doctrine, theory, and population. The author emphasizes that these ideas should be seen in the specific historical contexts in which they are put forward or discussed, in order to avoid the "sin of anachronism" or the problem of attributing modern ideas to historical contexts. The notion of cities, for example, implies quite distinct properties, depending on when the notion is formulated, whether at the time of Plato, or of Bodin, or of Colbert or Quesnay. This point—-the "Sin of Anachronism"-is elaborated in the Annex to Chapter 1, where the author discusses how some modern demographers (e.g., Demeny and Hutchinson) mistakenly claim that certain prescriptions such as "Go forth and multiply" in the Book of Genesis unquestionably favoured high population growth, or advocated high fertility. The idea of populationism as opposed to Malthusianism is not a valid argument in the case of historical societies. These ideas in historical societies were mainly geared to ensure the society's survival. "It is anachronistic to apply demographic concepts to early population thoughts" (p. 4).

Chapter 2 discusses whether Plato can be viewed as a possible "forerunner of demography," given his views of the "city" with a constant population size $(5,040)$ and other views that are actually "inseparable from the political divisions of fifth- and fourth-century Greece and the purely philosophical issue of justice in society" (p. 13). Although Plato's works touched on the familiar demographic issues of procreation, family, sexuality and marriage, the idea of historical relativity (or the related idea of the sin of anachronism) compels the author to conclude that "Plato cannot be seen as a precursor of demography, because the suggestions contained in Laws and in The Republic belong to another logical order" (p. 20) that is based on religious, political, and spatial perspectives. Yet, Plato's Republic and Laws were foundations of humanist scholarship that spread across Europe from the fourteenth century, particularly to legitimize monarchy as the "natural" form of government. 
Chapter 3 jumps one and a half millennia to come to Jean Bodin, a writer on political sovereignty, for whom populationism by itself was of little importance, except for the fact that political strength lies in numbers. Bodin dealt with topics related to population such as immigration and censuses of people, in particular of their property, for obvious fiscal reasons. To the reader's surprise, the author includes also a section on Bodin's ideas on sorcery; although an interesting topic, one fails to understand what sorcery had to do with the evolution of population thought in France! And, in the next section, the author comments extensively on Bodin's use of ideas from Plato and Aristotle in his political philosophy. Bodin's Six Books of the Commonwealth provided the core of absolutist writings on government, and population composition and size were seen simply as tools to legitimize the form of government.

Because of such ideas on population in terms of their relationship to the theory of political sovereignty, the author concludes that "politics transcended demographics," but "opened the way to the populationism of mercantilism, but it would certainly be wrong to regard him (Bodin) as a forerunner of mercantilism" (p. 62). Bodin's ideas were influential well into the eighteenth century, sustained principally by (Christian) religious thoughts on human reproduction and mortality.

Conceived originally against the Pope's spiritual and temporal powers, mercantilism flourished in France during the sixteenth and seventeenth centuries. Chapter 4 discusses the mercantilist views on population, largely in terms of the activities of the French Finance Minister Colbert, together with the works of Montchrétien and Fénelon, whose writings shifted from the political foundations to economic foundations of population thought. As the author says, "the mercantilists were populationists for two major reasons - one economic and the other political. A large population was needed to provide the labour force for agricultural and industrial production, to pay taxes, and to strengthen the county's military power. Thus population, economics and politics formed a triangle at the centre of which was populationism" (p. 65). Populationists favoured high fertility through the early and high rate of marriage, as well as through low infant mortality. A "doctrine" like this took into account major demographic variables such as fertility, marriage, mortality, and immigration. Although there were mercantilists in other parts of Europe, the author limits his study to those in France, because "France surpassed all other countries in its efforts to stimulate the increase in population by all conceivable means" (p. 68). Thus, the chapter focuses on the measures adopted by Colbertisme to secure the achievement of high population growth, including the Edict of 1666 for encouraging early marriages through fiscal means. However, "population was only potential wealth; it could become a resource for the kingdom only if it was developed economically and politically" (p. 73). Thus, labour and employment were promoted by measures such as forcing the idle poor to work, immigration, settlement of foreign artisans, favourable trade balance by only importing raw materials and exporting finished manufactures, and so on. The author gives a special account of the measures taken by French mercantilists to procure colonies and monopolize trade with them through national trading companies. Canadian readers will find the section "Populating Canada" interesting and informative, to see the devices mercantilists used to secure the population of French Canada. It is interesting to know, for example, that "Colbert was in favour of marriages with Indian women" by writing to the Intendant of Canada that "the Jesuits were wrong to discourage these unions in the name of the purity of religion" (p. 100). With such conflicting ideas on economy and politics, as the author says much earlier in the chapter, "mercantilism thus became an extension of bullionism but, at the same time, it was a negation of its principles" (p. 65) and "it was logical that it should begin to weaken when protests against absolutism grew towards the end of the Grand Siécle" (p. 102).

Chapter 5 turns to the physiocrats and their logical process towards political economy, achieved still within monarchical conceptions of government and population. The physiocrats, as critics of mercantilism, held agriculture to be the exclusive source of wealth; "neither industry nor commerce generated wealth" (p. 118). Thus, it was agricultural production that regulated population size and distribution through the labour market, an idea later picked up by political economists like Adam Smith, Thomas Malthus, and David Ricardo, and extended to all sectors of economic activity. François Quesnay was the "leader" of the physiocratic movement in France, and the physiocratic policies of "economic freedom"- freedom from industry and trade-were implemented when Turgot was the French Finance Minister. These policies lasted only for a very brief period (6 years, in contrast to the mercantilist policies, implemented for a much longer period of 150 years; p. 133). The physiocratic ideas led also to ideas of social classes and behaviour, especially in terms of subsistence versus luxury 
(luxe de subsistance vs luxe de decoration; p. 128). After dealing with other related ideas on population (for example, taxes and armies), the author discusses the failure of physiocracy due to its own "fundamental contradictions" outlined in the section so titled (p. 138), particularly by denying the role of politics in a theory of interaction between politics and economics. "But physiocracy's fundamental theoretical contribution- that population was economically determined—was to have a lasting success" (p. 141).

The concluding chapter, aptly titled "Towards Demography," goes back to what was outlined in the introductory chapter, and notes that the "extreme heterogeneity" between Plato, Bodin, the mercantilists, and physiocrats arises from their different contexts and from the strong "internal coherence" of the systems they constructed. Yet the current demographic indicators of human development, such as ability to survive, reproduce, and be mobile, were all there in their writings, which did not ignore the interactions between the political, social, and economic aspects of human population. However, for (modern) demography to arise, their idea of "absolutism" had to be replaced by individualism, as discussed in the section "The Emergence of Individualism" (p. 155). The revolutionary ideas from Spinoza (Tractatus Theologio-politicus) and Locke (Treatises on Government) weakened the religious and political foundations of absolutism that essentially controlled the behaviour of men and, particularly, of women. Adam Smith defined the individualistic concept of bomo aconomicus and theorized population dynamics in the context of wage theory. But the evolution of population thought had to wait for Malthus to develop the concept of homo demographicus and to "pave the definitive way for modern demography" (p. 162). Malthus' Essay on the Principle of Population integrated the demographic ideas on mortality, nuptiality, fertility, and mobility, as well as the adjustment mechanisms of fertility (contraception, age at marriage) and mortality (epidemics, famines, wars) — thus, for the first time in history to speak of interactions between these demographic variables.

In sum, this book contributes an in-depth look into the historical evolution of ideas on population over almost two millennia, from Plato to Quesnay. Concentrating on a few players, especially those on French soil, might have served the purpose of an author from Centre Population et Développement, but all these ideas belong to a period before solid demographic ideas were actually developed (since the 18 th century). To call these ideas "classical foundations" may be an exaggeration, especially as the book's French bias neglects many interesting ideas from thinkers outside of France during the three centuries covered in this book. A better title of the book could read something like The Foundations of French Population Thought. Apart from very brief mentions of contributions made by political arithmeticians like Davenant, Petty, Graunt, Locke, and Hobbes, readers looking for more information on the evolution of population thought over the seventeenth and eighteenth centuries will find this book a bit disappointing. Ironically enough, a book that deals predominantly with the evolution of French population thought ends with a glorious tribute to the major contributions made by English thought, especially by Malthus! As a final note, readers might be cautioned that the writing style of the author contains some monotonous repetition of ideas and many grammatical errors, particularly in the earlier chapters. 